\title{
Progress of Human Geography in Asia: Editorial Note
}

\section{KANASAKA Kiyonori, OKUNO Shii, OGATA Noboru, \\ TAKAYAMA Masaki, and IKUTA Masato}

\section{Prologue}

Why has the Japanese Journal of Human Geography started the project of publishing a Special Issue on the progress of human geography in Asia? What is the significance of this project in this era of global change, national transformation, with increasing international exchange ? What regions / nations are participating in this project? What are the social and environmental factors that have affected the development of human geographical knowledge in this region? What are the future prospects of this project?

\section{(1) Society changes in East Asia}

It is now sixty-one years after the end of Second World War at 1945. East Asia has been greatly transforming herself in physical development such as housing development, education and medical service provision, urbanization, industrial production and export, high-tech developments, domestic transport network and urban subway system, international routes and hub-port (airport) development, and so on. Traditional communities have been changed into metropolitan or new town communities, and after a lapse of forty years or more, some of these new towns are now facing "old-town problems" such as rapid aging of resident population, public facilities turning obsolete, and move of these aged residents back to new residential (re) developments nearby the city center.

In the last half-century some nations or regions in East Asia have made their recovery and development success, for example, Japan, Singapore, Hong Kong, Korea and Taiwan. In early twenty-first century, the gross domestic product per capita of Japan, Singapore, Hong Kong rank similar to those industrially advanced countries, and some high-tech industries like automobiles, integrated circuits, mobile phones, notebook computers, liquid-crystal display panels, plasma display panels and animation are produced and innovated from this region. Nations in Southeast and South Asia are following suit, and making serious steps to develop their local or high-tech industries to fight for a place in the global arena of production, or in the international division of labor process.

These society changes have been directed with central or local government legislation and 
policies such as export-oriented industrialization policies, high-tech industrial estate development or export-processing zone / special economic zone development, or industrial cluster formation. These public laws or policies also call for development in education sector, school facilities and teacher training. A lot of national education systems since 1950s have already been providing basic education up to fifteen years of age, or nine years of compulsory education. Universities or teacher training colleges are given the important duty to train high and middle school teachers, and to educate manpower for industrial, business, service, and government sectors. Some governments have also encouraged or supported selected students to study abroad to grasp the advanced part of world knowledge production and a language skill. Moreover, since early 1990s, some governments have began to strengthen higher education at university level for nurturing the needed business and technological skills to support private and public sectors for global challenge as well.

\section{(2) Geography departments in Asia}

A lot of geography departments in Asia have a legacy from the colonial past. This colonial influence has greatly shaped the department buildup in various ways. The British system of geography department demands an integrated approach to man and environment, calls for a balance of sub-disciplines between physical and human geography, and tends to place the department in the faculty of science. The United States system tends to separate geography into geo-science, humanities or social science, or behavioral science. Departments with emphasis in human geography usually find their place in faculties of social science, arts, or humanities. Soviet geography places more emphases on physical, economic and less on the impacts of human agency. In the buildup, soviet university system used to place the geography department among the science faculties.

In late 1990s, a lot of universities have faced contraction if not insufficiency in funding. Academic performance evaluation or accreditation is employed to make teaching staffs to produce more and better. The slogan of "To publish or to perish !" from USA universities always urge their Asian counterpart to do their best. Under practice in some university system, the academic credits of all staff, number of student enrolment, and their professional contribution to society, are graded collectively to evaluate the department's team performance. Successful departments are provided with more research funds and the less successful with less or minimum grants. Some nations adopt the Centers of Excellence to support projects with the base of a strong graduate school and with the possibilities of forming an innovative core in world arena of knowledge or academic societies.

\section{(3) Individual research and teaching efforts in geography}

Individual research / teaching staff in (human) geography, aiming to promote his or her career, has to produce publications, teach the classes, stimulate the students to think more, involve in public policy making, or do research projects, with their professional knowledge. Allan Pred told about his own paths and projects in the Special Issue commemorating the Seventy-fifth Anniversary of American Association of Geographers, he said how he had selected his academic 


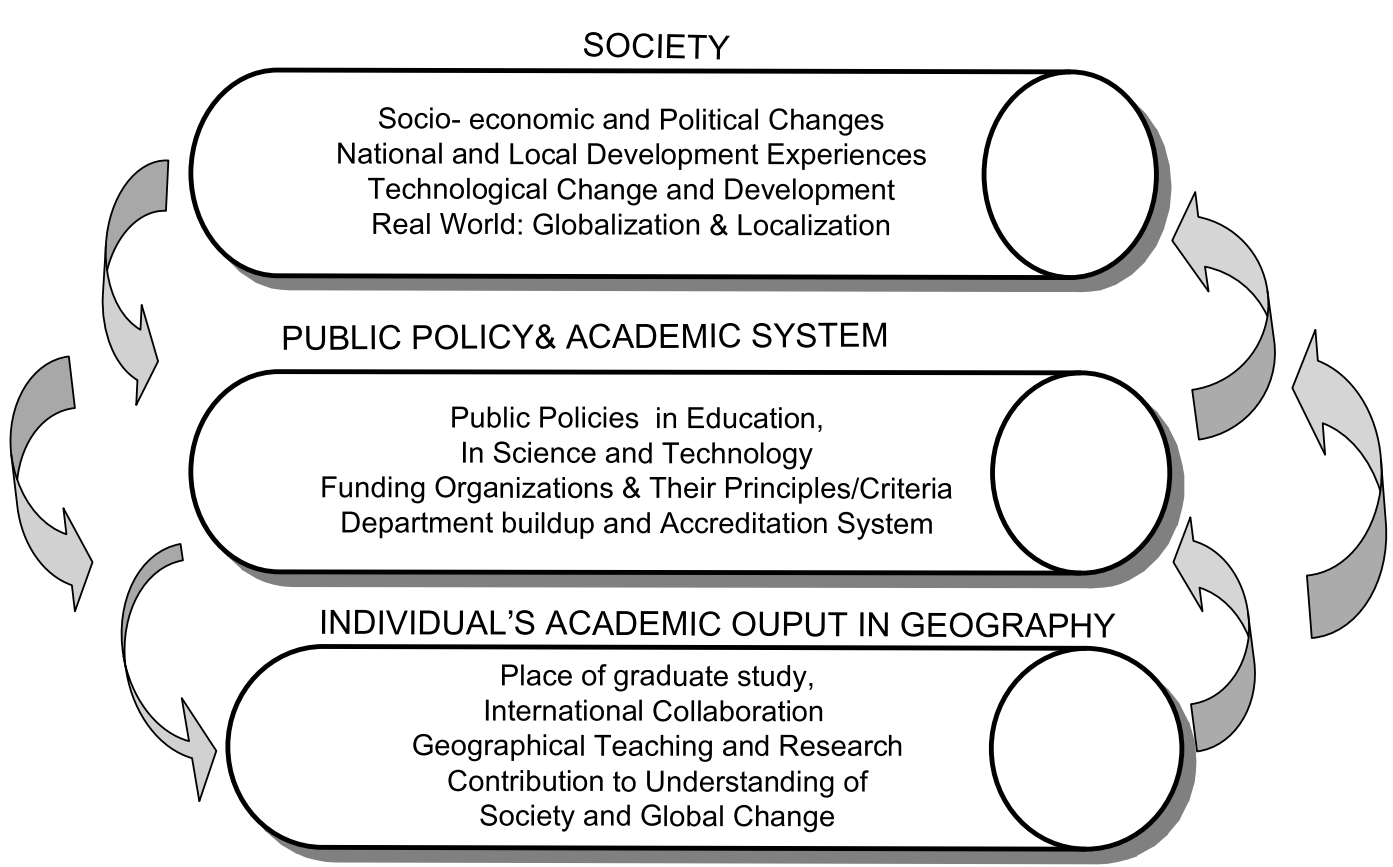

Figure 1. Interrelationships among society, public policy / academic system and individual's academic output (Produced by S. Okuno)

paths / pursuits upon evaluating different opportunities, and that producing his publications were his projects. Individuals design their paths in the future. Overseas graduate study of Asian geographers provides them a chance to grasp the modern geographical knowledge development, its methodology and way of thinking, and much more, a circle of peers and colleagues. Some of them choose to return to their home country and help the discipline to develop. Some succeed to get a job to stay in the United States or United Kingdom, and help strengthen the development of Asian geography in theory and practice and establish links with the counterparts in Asia. Individual research themes are often influenced by funding program criteria, or advices from peers in the same field.

The above-mentioned interrelationships are illustrated in Figure 1, with emphases on the interplay of these three agencies. They may promote, or sometimes, cause barriers in, the development of geographical knowledge in various regions, and in Asia in particular. Stoddart's earlier conceptual framework for the discipline of geography and its social concern should be acknowledged as it provides an inspiration to this figure construction.

\section{(4) Regions / nations participating in this Project}

In this Project of Progress of Human Geography in Asia, we have, through personal relationships, contacted our counterpart geographers in China, India, Indonesia, Japan, Korea, Malaysia, Singapore, Taiwan, Thailand and Vietnam to contribute. Some work according to the

1) Stoddart, D. R., Geography, Ideology and Social Concern, Blackwell, 1986. 
schedule and some at a slower pace. In this current issue, on the first-come-first-served basis, we have gathered four articles, namely from Singapore, Taiwan, and Korea (Republic of Korea), and Vietnam. The rest will be published in the next Special Issue, scheduled to come out in late 2007 or early 2008.

\section{(5) Our goals}

Our goals of this project are threefold. First, we like to explore the background for the geographical knowledge that has developed in different national / local contexts, and the diversified ways that geographers frame their research projects or plan their paths in response to this challenge. An exchange of the participating nations' experiences will certainly provide the basis for future exchange activities to follow. Second, a lot of nations / regions in East Asia region face similar challenges of disurbanization, aging, depopulation, and very low fertility rate. Some coordinated research projects, or international comparison studies will help clarify the factors leading to such social phenomenon or process, and reveal policy implications. Third, we hope the experience and expertise of the Asian geographical knowledge should somehow become a core in the future, challenging those of USA and Europe.

\section{Contributions}

In the following we shall highlight the four articles that are included in this issue.

\section{(1) Progress in Singapore}

Victor Savage of the Geography Department at National University of Singapore (NUS), outlines the works of present generation of Singaporean geographers as second generation, and informs that most of the teaching staff have graduated from graduate schools in United Kingdom or USA. Singapore, as a research arena, is often taken as a nation, a city, and an ecosystem as well. To summarize in Savage's own words, the first trunk of geographical works can be understood by reading the following paragraph :

"One body of work deals with the whole issue of Singapore finding its identity and footage as a nation-state. A second body of thought attempts to look at Singapore as a city with places of embedding community bonds, ethnic identity and nostalgic relationships. And a third body of literature looks at the dynamics of Singapore as an urban ecosystem, its urban sustainability, and its brown and green issues."

Besides, the migrant population at high and low ends and their community provide rich resource for research. Migrants, diaspora, and labor migration in Singapore and the region are well covered. As a lot of Philippines women work as domestic helpers in Singapore, the gender issue concerns itself with feminist geographies, research have been done on the national identity tensions, legal coverage and issues, health related problems, labor relationships and so on.

Globalization, global cities, cosmopolitan population and local dialogue form the third trunk of

2) Savage is the current President of the Association of Commonwealth Geographers. 
their research. Henry Yeung's research on Hong Kong and Singapore transnational corporations (TNCc) and Chinese business indicated that TNC is not placeless, and hinted the same for capitalism. He also critically analyzed the nature of relationality and power relations, and initiated the so-called 'relational turn' in economic geography'. Works on global retailing, global environmental change and Singapore response, and thoughtful work on politics of forgetting, indicating those forgotten and marginalized places being played out by global, national and local actors in globalization processes.

\section{(2) Progress in Taiwan}

Nora Chiang and Sue-Ching Jou of the Department of Geography at National Taiwan University (NTU) have carefully surveyed the major journals in the last decade with a bibliometric approach to categorize the published articles quantitatively and found out four clusters as a result. They are : environmental management and behavioral geography ; economic geography and regional development; social / cultural, urban geography and tourism; population and migration, and transportation geography.

Now five universities in Taiwan have established the department of geography, i. e., the NTU, National Taiwan Normal University, Chinese Cultural University, Changhua University of Education, and Kaohsiung University of Education.

They have also surveyed the specialties of geographers holding posts in these universities at two periods : 2001 and 2006. Studying the difference between the two periods show those newly added posts / specialties are : geography of place names, geography of everyday life, geography of fishery and agriculture, hazard prevention education, multimedia for geographical learning, community development and planning, Taiwanese business people and high-tech industry, spatial behavior, gender and society, population migration, public participation, ethnic relations, space and society, location analysis, theory of regional planning, urban and regional planning, regional economy and industrial development. Existing emphases that get additional staff are historical geography, medical geography, tourism geography (recreation and leisure), aboriginal studies, and local studies in geography. To our surprise, our calculation finds out that the total number of staff of these universities with specialties in geography has decreased from 181 to 139 persons, and the large categories of human geography, geographical education, environmental resources and land use, regional geography, geographical thoughts, regional development have all lost academic staff, against which the category of special or applied geographical topics has managed to gain staff number.

\section{(3) Progress in Korea}

BAEK Seonhae of Department of Digital City at the Seoul Development Institute of Korea pointed out that Korean Geographical Society was established in 1945. Modern Korean

3) Yeung, H. W. C., "Rethinking relational economic geography," Transactions Institute of British Geographers, 30, 2004, pp. 37-51.

4) Lee, Y. S. and Yeoh, B. S. A., eds., Globalisation and the Politics of Forgetting, Routledge, 2006.

5) Sue-Ching Jou is head of the Department of Geography at NTU. 
geographical development can be divided into five periods: the 1960s (Period of Foundation), the 1970s (Infancy Period), the 1980s (Period of Growth), the 1990s (Jump and Rush Period), and early 2000s (Period of Maturity and Globalization). Korean geographers have attempted to study the real world and their changes, for example, urbanization, industrialization, economic development, and recent cultural turns. Rapid development has been found in the latest period as these fourth-generation geographers got their education from professors that have overseas experience and methodology. This group of young professionals is now active in national policy institutes and university departments. Geographers in Korea have been active in conducting applied research for policy-making and in promoting the discipline of geography.

Baek has also outlined important contributions of the last decade in the fields of : cultural and historical geography; economic geography (agricultural, industrial, commercial, services and distribution activities); urban geography ; rural geography ; social, population and political geography; regional studies : and others (applied geography, tourism). Lastly he remarked that Korean human geographers are more ready to contribute to social needs, to interdisciplinary studies, and international cooperation, a case very similar to that of Taiwan.

\section{(4) Progress in Vietnam}

NGUYEN Cao Huan, NOMA Haruo, and NGUYEN Duc Kha, and TRAN Anh Tuan have jointly compiled a historical survey on the development of geography in Vietnam. They described briefly the past feudal period with application of geographical knowledge at land demarcation. They then provided a detailed survey on the French Period in the early twentieth century, with the characteristics of regional geography, human geography, and applied research on irrigation system development, industrial plant location, and resort location. The work of P. Gourou on human geography and agricultural production was respected for his humanism and multi-dimensional details.

Soviet geography influence was very strong in the early modern geography in 1954-1975 in Vietnam and geographical departments are found in two universities in Hanoi (Hanoi National University and Hanoi Pedagogic University). In the next period (1975-86), the concepts and methodology of Soviet geography were applied to investigate the natural and socioeconomic conditions for regional development in Central Highland, the Southeast, Mekong River Delta region, and the South Central Regions. Geographical departments have been established at four more universities or research institutions located in three regions.

In the present period (1986 to present) one sees an increasing number of geographical research on natural resource assessment, environmental conservation at different spatial levels (regional, local and community levels) and sustainable development. Geographers can get numerous opportunities to exchange with foreign experts and academics. Modern courses include Geographic Information Systems and Remote Sensing in the curriculum. A notable national research project in this period was the Territorial Organization of the Red River Delta Region (1986 -1995). One can say, the mainstream of geographical studies in Vietnam has been based on geomorphology, landscape ecology and environment, and cartography. The new research areas after 1996 include human geography, ecological economics, and land administration. 


\section{Prospects}

After completing the second Special Issue on Progress of Human Geography in Asia, we plan to put the collection of these two Special Issues into a book form. In doing so, we also realize the lacking of information and participation from West Asia. We shall seek opportunities to get geographers in Turkey and in Iran to participate to write on the progress of their discipline there.

TAKEUCHI Keiichi, a famous Japanese scholar who published several works on the geographical thoughts of Japanese geographers in early formation of Modern Japan up till now, passed away in 2005. We shall make our best efforts to complete this project and report to Takeuchi in our meditation that one of his wishes of extending his project into Asia will be fulfilled by then.

We shall also give a pleasant surprise to the centers of geographical knowledge cores in USA or Europe that the East is arising. Scholars at different place practice differently. Geographical knowledge is developed from practice and learning, and always influenced by society and shaped by public policy and academic system. With a difference of society and academic system, we expect many different streams / fields of geographical knowledge will develop, cherish, fulfill the needs of their local concern, and meet the challenge of global environment.

6) Takeuchi, Keiichi, Modern Japanese Geography: An Intellectual History, Kokon Shoin, 2000. 